\title{
Priority of Disease Contact
}

National Cancer Institute

\section{Source}

National Cancer Institute. Priority of Disease Contact. NCI Thesaurus. Code C102699.

The categ orization of individuals with or without the potential for having tuberculosis. 